\title{
Type Curve Techniques for Hydraulically Fractured Wells in Tight Gas Reservoir
}

\author{
Luis Ramírez, M.Sc. ${ }^{1}$, Danilo Arcentales, M.Sc. ${ }^{1}$, Kenny Escobar, M.Sc. ${ }^{1}$, and Omar Al-Fatlawi, PhD. ${ }^{2}$ \\ ${ }^{1}$ Escuela Superior Politécnica del Litoral, ESPOL, Facultad de Ingeniería en Ciencias de la Tierra, Campus Gustavo Galindo Km. \\ 30.5 Vía Perimetral, P.O. Box 09-01-5863, Guayaquil, Ecuador,viramire@espol.edu.ec,_daanarce@espol.edu.ec, \\ kescobar@espol.edu.ec \\ ${ }^{2}$ Curtin University, Perth - Australia, omer_fh2003@yahoo.com
}

\begin{abstract}
Tight gas sand is characterized for having low productivity and permeability in which low gas flow rate is provided. The application of hydraulic fracturing known as stimulation technique has been used to produce gas at economic rates. However, a common problem in tight gas reservoir simulation is the representation of hydraulic fracture in reservoir modelling. This is a crucial challenge for numerical simulation in which erroneous values of pressure distribution are generated, resulting in the calculation of unrealistic cumulative gas production. As a reliable solution, the use of Local Grid Refinement (LGR) simulation technique is applied around the wellbore and parallel to the fracture increasing the resolution of pressure behavior to adequate properly the hydraulic fracture in the reservoir modelling.
\end{abstract}

In this paper, the results of simulation for Whicher-Range (WR), a tight gas field in Western Australia, were analyzed and used to generate the type curves for finite flow capacity in vertical fractured wells. Although the curves behavior was completely different to the type curves in conventional reservoirs, the development of engineering plot generated based on the same simulation results matched perfectly on the type curves predicting the gas production as well as validating the effectiveness of LGR method in numerical simulation of tight gas reservoir.

The generation of type curves for hydraulic fractured wells in tight gas reservoir has never been presented and proven for Whicher Range field before. Also, the reformulated method based on the research by Argawal, Carter and Pollock of type curves are much faster than using numerical simulator which is time consuming and high CPU cost. In this paper, the successful method proven is a fast and effective way to predict the gas production for a single hydraulic fractured well in tight gas reservoir without any problem of using any commercial software.

Keywords-Tight gas, hydraulic fracturing, reservoir modelling, LGR, type curves.

\section{INTRODUCTION}

Production optimization of tight gas reservoir is an important task, in which an increase of gas production is achieved in order to obtain high incomes for the company. However, the process of reservoir modelling of Tight gas is a challenging task to the numerical simulation Engineers. Because of its geological complexity and low permeability less than $0.1 \mathrm{md}$ which the gas flow is very slow.

Digital Object Identifier (DOI):

http://dx.doi.org/10.18687/LACCEI2019.1.1.230

ISBN: 978-0-9993443-6-1 ISSN: 2414-6390
This is even more difficult to develop than conventional reservoir, due to size of low permeability reservoir which is much larger.

The most popular and generally accepted method for representing hydraulic fractures in numerical simulator is LGR. The method allows to design of grid cells dimension that is adequate to represent the fracture half- length and width [1]. In transient flow, the explicit calculation can be given by LGR as advantage. The primary function of running simulations with LGR ensures that explicit calculation for transient flow are generated. In the case of conventional reservoir, the transient flow period can be short in comparison to a significantly longer period as in the case of unconventional reservoir. According to Wattenbarger, El-Banbi et al. (1998) observed the linear flow regime stays for several years in very tight gas reservoir in which hydraulic fracture may have been designed to extend the drainage area of the well [2]. The linear flow may be the dominant flow regime during the production life in which pseudo radial flow is not observed and expected.

As much as the LGR approach is effective, we shall also skim through two approaches that use the principle of steady state. The Pseudo - K approach, proposed by El-Ahmady (2004) is based on the principle that permeabilities increase in most simulation cells which are adjoining well perforations representing most hydraulic fractures [3]. Another approach using the steady state principle is the Well Index approach proposed by Nghiem (1983) and revised by Abacioglu, Sebastian et al. (2009) where in the hydraulic fractures are treated as a part of the well. But the Well Index is calibrated such that it represents planar flow instead of the commercially used radial flow [4][5]. Though the empirical expressions for both these methods are quite elementary, they need to be recalibrated before every application.

According to Bonney, Abacioglu et al. (2013) presented a method for representing hydraulic fracture in tight gas reservoir using LGR [6]. The assumption was that the allocation of all fractures had to be parallel to either in I or $\mathbf{J}$ axis of the reservoir simulator. The grid blocks located parallel to the fractures and perpendicular to the fracture which containing both fracture and well were refined as shown in the following Fig. 1.

Azim and Abdelmoneim (2013) point out the increase of resolution by using LGR can solve other problems in model simulation [7]. For example, in the modelling of gas coning

$17^{\text {th }}$ LACCEI International Multi-Conference for Engineering, Education, and Technology: "Industry, Innovation, And Infrastructure for Sustainable Cities and Communities", 24-26 July 2019, Jamaica. 
near the horizontal well as shown in the Fig. 2. A tracking of gas front can be performed accurately estimating time and position of the gas breakthrough in the well.

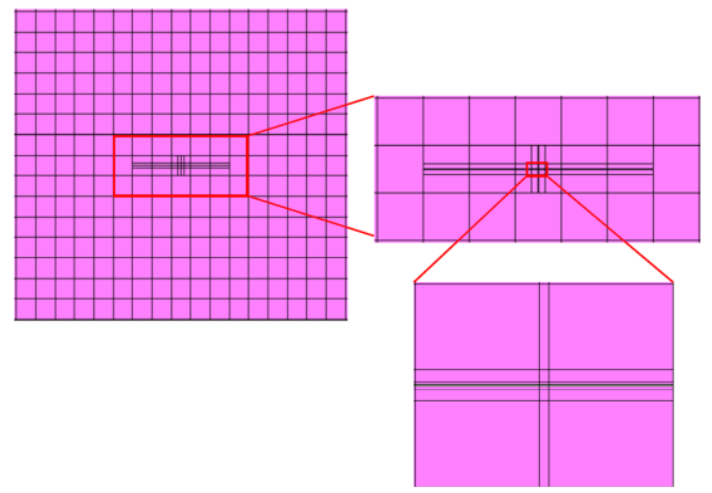

Fig. 1 LGR applied on vertical fractured well [6]

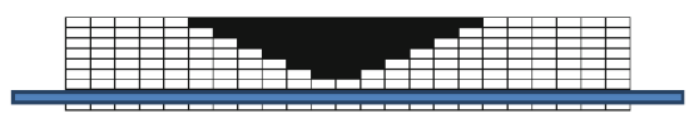

Fig. 1 Gas Coning near a horizontal well [7]

In this paper, we pursuit two objectives: First, performing the sensitivity analysis of half fracture length to optimize the gas production of tight gas reservoir applying Local Grid Refinement (LGR). Second, the application of such sensitivity results in the new type curve which method was reformulated based on the research by Argawal et al (1987), to validate and prove the outcomes of reservoir simulation in combination of LGR technique as well as a curve fitting on the type curves [8].

\section{BACKGROUND}

Whicher range is a tight gas reservoir which is located 280 $\mathrm{Km}$, south of Perth Basin. The location of this field is between Bundury Trough and Vasse Shelf. The main sand is hosted by Willespie formation which is comprised of shales and coal layers. The Permian Willespie Formation occurs at a depth range of 3700 to $4300 \mathrm{~m}$. The well stratigraphy shows a change of lithology in the Top Willespie Formation, which includes an increase of coals and carbonaceous shales.

This is followed by a critical composition variation of the sandstones, this unconformity has been verified through log analysis. The characteristics of sandstones are highly changeable from fine to coarse grained size and comprised of quartz, feldspar, garnet, micas and heavy minerals. According to Western Australian Energy Research Alliance (2012), the average of effective and total porosity is $2 \%$ and $9.7 \%$, respectively, describing a reservoir with poor quality and low permeability [8]. It is estimated that gas in place reaches over 5 TCF in which 5 wells had been drilled.

\section{METHODOLOGY}

This methodology is divided in two sections. The First section shows the steps that were applied to optimize the gas production using reservoir modelling with LGR technique. Several sensitivity analyses of fracture half-length and fracture conductivity were carried out to identify the most influenced fracture parameter in the gas production.

The second section explains how to generate the type curves for vertical fractured wells, this reformulated method was validated through the curve fitting using Engineering plot for Tight Gas Reservoir:

First section, optimizing the gas production in Tight Gas Sand.

The first section was made of the following steps described below:

\section{Developing the reservoir modelling}

Building a reservoir simulation model is an important task in which well data was used to simulate the production of Whicher Range (WR) a Tight Gas field in Western Australia. In WR field, 5 wells were drilled since the first discovery in 1960’s.

The Data collected involved Core, Production data and logs, which allowed to perform five fundamental studies such as Reservoir, Production, Petrophysics, Geology, Drilling and Stimulation.

The reservoir model was created through the Rubis Platform belonging to ECRIN-KAPPA software (version 4.30.08).

\section{Simulating the Tight gas reservoir applying LGR technique}

Having built the reservoir model in Rubis platform of Kappa Software, the hydraulic fractures can be input through fractured well option located in the toolbar. Modifying the fracture input the data of fracture properties can deliver results on the simulation engineer requirements.

Afterward, in order to input the type and size of grid block for wells or reservoir, we take a look on the grid option which displays the upscaling range from 0 to 1 indicating the subdivision of cells to increase the resolution. For this case, the value of 0.2 as very fine grid size was input in the cells around the well and hydraulic fracture shown in Figure 3 and 4. 


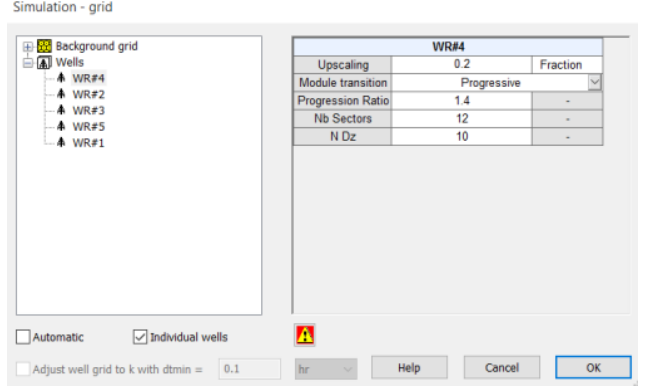

Fig. 3 Gridding Option

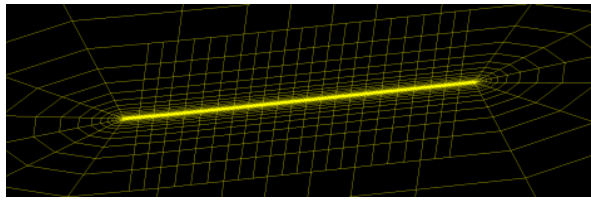

Fig. 4 Local Grid Refinement

Performing the sensitivity curves with different half-length fracture and fracture conductivity

After running the simulation for three different scenarios: 5,8 and 10 years, variables of fracture conductivity, fracture half-length and gas cumulative production were considered to develop the sensitivity curve. The range values of $X_{f}$ and $F_{c}$ taken in the simulation were from 100 to $500 \mathrm{ft}$ and from 1000 to $5000 \mathrm{mD} * \mathrm{ft}$ respectively as shown in Table 1 . For plotting the sensitivity curve, the range of fracture half-length was plotted against gas cumulative production for different values of fracture conductivity previously mentioned. The plots and simulation results generated are discussed in a later section.

TABLE 1

VALUES OF HALF-LENGTH FRACTURE AND FRACTURE CONDUCTIVITY USED IN THE SIMULATION

\begin{tabular}{|c|c|}
\hline $\mathrm{Fc}(\mathrm{mD} * \mathrm{ft})$ & $\mathrm{Xf}(\mathrm{ft})$ \\
\hline 1000 & 100 \\
\hline 2000 & 200 \\
\hline 3000 & 300 \\
\hline 4000 & 400 \\
\hline 5000 & 500 \\
\hline
\end{tabular}

Second section, creating the type curves for Vertical Fractured wells in Tight Gas Sand

The second section was assembled using the following steps:

Replacing the results of simulation, such as cumulative gas production and time on the formulas described by Argawal, Carte y Pollock.

Based on the research by Agarwal, Carter et al. (1979), the type curves are used for evaluation performance of low permeability Gas Wells stimulated by Massive Hydraulic
Fracturing [9]. The finite Flow-Capacity type curves with constant pressure is applied to WR field. The type curves include several parameters like reciprocal of the dimensionless rate, which is function of dimensionless time with dimensionless fracture flow capacity on $\log$-log paper as showed in Eq 1, Eq 2 and Eq 3. The Tables 2 and 3 show the reservoir data used in the creation of type curves as well as an example plot of finite flow-capacity in hydraulic fractured wells in Tight Sands (Figure 5).

$$
\begin{gathered}
\mathrm{t}_{\mathrm{D}_{\mathrm{x}_{\mathrm{f}}}}=\frac{2 \cdot 6 \mathrm{~A} 4 \cdot 10^{-4} \mathrm{kt}}{\phi\left(\mathrm{p} \mathrm{c}_{\mathrm{t}}\right) \mathrm{x}_{\mathrm{f}}^{2}} \\
\frac{1}{q_{D}}=\frac{\mathrm{kh} \Delta[\mathrm{m}[\mathrm{p})]}{1424 \mathrm{q} \mathrm{T}^{0}} \\
\mathrm{~F}_{\mathrm{CD}} * \mathrm{kx}_{\mathrm{f}}=\mathrm{k}_{\mathrm{f}} \mathrm{W}
\end{gathered}
$$

TABLE 2

RESERVOIR DATA USED ON TYPE CURVES FORMULAS

\begin{tabular}{|c|cc|c|cl|}
\hline \multicolumn{3}{|c|}{ Well \# 1 } & \multicolumn{3}{c|}{ Well \# 4 } \\
\hline$\varphi$ & 0.1427 & $\begin{array}{l}\text { fraction } \\
\mathrm{PV}\end{array}$ & $\varphi$ & 0.1712 & $\begin{array}{l}\text { fraction } \\
\text { PV }\end{array}$ \\
\hline$\mu$ & 0.03 & $\mathrm{cp}$ & $\mu$ & 0.03 & $\mathrm{cp}$ \\
\hline $\mathrm{h}$ & 11.50 & feet & $\mathrm{h}$ & 52.80 & feet \\
\hline $\mathrm{K}$ & 0.2004 & $\mathrm{md} * \mathrm{ft}$ & $\mathrm{K}$ & 0.0552 & $\mathrm{md} * \mathrm{ft}$ \\
\hline $\mathrm{Temp}$ & 669.67 & Rankin & $\mathrm{Temp}$ & 669.67 & Rankin \\
\hline $\mathrm{Ct}$ & 0.03 & $\mathrm{psi}-1$ & $\mathrm{Ct}$ & 0.03 & $\mathrm{psi}-1$ \\
\hline$\Delta \mathrm{m}(\mathrm{p})$ & $7.69 \mathrm{E}+08$ & $\begin{array}{l}\mathrm{psi}- \\
2 / \mathrm{cp}\end{array}$ & $\Delta \mathrm{m}(\mathrm{p})$ & $7.69 \mathrm{E}+08$ & $\begin{array}{l}\mathrm{psi}- \\
2 / \mathrm{cp}\end{array}$ \\
\hline $\begin{array}{c}\text { Reservoir } \\
\text { Pressure }\end{array}$ & \multicolumn{2}{|c|}{$5584 \mathrm{psi}$} & $\begin{array}{c}\text { Reservoir } \\
\text { Pressure }\end{array}$ & $5584 \mathrm{psi}$ \\
\hline
\end{tabular}

TABLE 3

VALUES OF FRACTURE CONDUCTIVITY, FCD AND Xf

\begin{tabular}{|c|c|c|c|c|c|}
\hline \multicolumn{3}{|c|}{ Well \#1 } & \multicolumn{3}{c|}{ Well \#4 } \\
\hline \multirow{2}{*}{ FCD } & $\begin{array}{c}\text { Xf } \\
(\mathrm{ft})\end{array}$ & $\begin{array}{c}\text { Fracture } \\
\text { Conductivity }\end{array}$ & FCD & $\begin{array}{c}\text { Xf } \\
\text { (ft) }\end{array}$ & $\begin{array}{c}\text { Fracture } \\
\text { Conductivity }\end{array}$ \\
\hline 5000 & 200 & 200363 & 5000 & 200 & 55170 \\
& 150 & 150272 & & 150 & 41378 \\
& 100 & 100182 & & 100 & 27585 \\
& 75 & 75136 & & 75 & 20689 \\
\hline 1000 & 200 & 40073 & 1000 & 200 & 11034 \\
& 150 & 30054 & & 150 & 8276 \\
& 100 & 20036 & & 100 & 5517 \\
& 75 & 15027 & & 75 & 4138 \\
\hline 500 & 200 & 20036 & 500 & 200 & 5517 \\
& 150 & 15027 & & 150 & 4138 \\
& 100 & 10018 & & 100 & 2759 \\
& 75 & 7514 & & 75 & 2069 \\
\hline 50 & 200 & 2004 & 50 & 200 & 552 \\
& 150 & 1503 & & 150 & 414 \\
& 100 & 1002 & & 100 & 276 \\
& 75 & 751 & & 75 & 207 \\
\hline
\end{tabular}

$17^{\text {th }}$ LACCEI International Multi-Conference for Engineering, Education, and Technology: "Industry, Innovation, And Infrastructure for Sustainable Cities and Communities", 24-26 July 2019, Jamaica. 


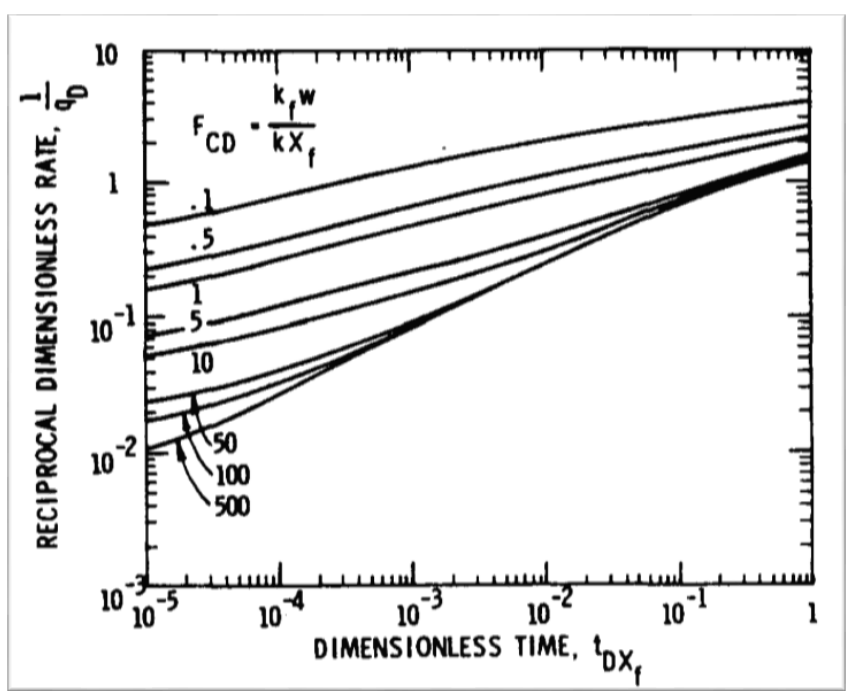

Fig. 5 Type curve for finite-flow capacity [9]

\section{Generating the engineering plot to develop the type curves matching technique}

A graphical technique known as type curve method is used to solve transient flow problems by curve matching. Theis (1935) discovered this matching technique for hydrology problems, and after that the petroleum industry has adapted it since 1970 [10].
In order to use the Finite Flow-Capacity Type curves at Constant Pressure, the reciprocal of flow rate vs time "Field data" have to be plotted on a tracing paper using logarithm graphical scale. The points drawn on the tracing paper must be shifted both horizontally and vertically on the type curve until a fitting curve is obtained. Both real and dimensionless values of match point are read and recorded, with appropriate dimensionless flow capacity. Further details can be found in the paper SPE-6838-PA.

\section{RESULTS}

The results in the first section shows that the Cumulative Gas Production increases as long as half-length fracture is greater as well as the fracture conductivity. The table 6,7 and 8 explain in detail the impact of half-length fracture on cumulative gas production as extremely significant. In comparison of fracture conductivity, this variable has no a strong influence on cumulative gas production. Analyzing the tables 4, 5 and 6 , a tight gas well with a $X_{f}$ of 500 feet produces $4.52 \mathrm{bscf}$ more than a $X_{f}$ of 100 feet in the simulation for 5 years. Our results shows that a larger fracture length has an important impact on cumulative gas recovery than the amount of fracture, which are consistent in both methodology and analysis with two previous publications made by different authors as Ostojic, Rezaee et al. (2012) and Pankaj and Kumar (2010) " $[11][12]$.

TABLE 4

SIMULATION FOR 5 YEARS

\begin{tabular}{|c|c|c|c|c|c|c|c|c|c|}
\hline \multicolumn{2}{|c|}{$F \mathrm{c}=5000$ md.ft } & \multicolumn{2}{|c|}{$F \mathrm{c}=4000$ md.ft } & \multicolumn{2}{c|}{$\mathrm{Fc}=3000 \mathrm{md} . \mathrm{ft}$} & \multicolumn{2}{|c|}{$F \mathrm{c}=2000 \mathrm{md} . \mathrm{ft}$} & \multicolumn{2}{c|}{$\mathrm{Fc}=1000 \mathrm{md} . \mathrm{ft}$} \\
\hline $\mathrm{Xf}(\mathrm{ft})$ & $\mathrm{Gp}(\mathrm{bscf})$ & $\mathrm{Xf}(\mathrm{ft})$ & $\mathrm{Gp}(\mathrm{bscf})$ & $\mathrm{Xf}(\mathrm{ft})$ & $\mathrm{Gp}(\mathrm{bscf})$ & $\mathrm{Xf}(\mathrm{ft})$ & $\mathrm{Gp}(\mathrm{bscf})$ & $\mathrm{Xf}(\mathrm{ft})$ & $\mathrm{Gp}(\mathrm{bscf})$ \\
\hline 100 & 10.85530 & 100 & 10.8295 & 100 & 10.821 & 100 & 10.8034 & 100 & 10.75256 \\
\hline 200 & 12.5343 & 200 & 12.5219 & 200 & 12.4998 & 200 & 12.4579 & 200 & 12.3347 \\
\hline 300 & 13.7014 & 300 & 13.6784 & 300 & 13.64 & 300 & 13.5666 & 300 & 13.356 \\
\hline 400 & 14.6236 & 400 & 14.5888 & 400 & 14.5324 & 400 & 14.4222 & 400 & 14.1149 \\
\hline 500 & 15.3766 & 500 & 15.3283 & 500 & 15.2515 & 500 & 15.101 & 500 & 14.6853 \\
\hline
\end{tabular}

TABLE 5

SIMULATION FOR 8 YEARS

\begin{tabular}{|c|c|c|c|c|c|c|c|c|c|}
\hline \multicolumn{2}{|c|}{$\mathrm{Fc}=5000 \mathrm{md} . \mathrm{ft}$} & \multicolumn{2}{c|}{$\mathrm{Fc}=4000 \mathrm{md} . \mathrm{ft}$} & $\mathrm{Fc}=3000 \mathrm{md} . \mathrm{ft}$ & \multicolumn{2}{c|}{$\mathrm{Fc}=2000 \mathrm{md} . \mathrm{ft}$} & \multicolumn{2}{c|}{$\mathrm{Fc}=1000 \mathrm{md} . \mathrm{ft}$} \\
\hline $\mathrm{Xf}(\mathrm{ft})$ & Gp (bscf) & $\mathrm{Xf}(\mathrm{ft})$ & Gp (bscf) & $\mathrm{Xf}(\mathrm{ft})$ & Gp (bscf) & $\mathrm{Xf}(\mathrm{ft})$ & Gp (bscf) & $\mathrm{Xf}(\mathrm{ft})$ & Gp (bscf) \\
\hline 100 & 15.33050 & 100 & 15.32480 & 100 & 15.31380 & 100 & 15.29230 & 100 & 15.22860 \\
\hline 200 & 17.4542 & 200 & 17.439 & 200 & 17.4133 & 200 & 17.3617 & 200 & 17.2124 \\
\hline 300 & 18.8744 & 300 & 18.8463 & 300 & 18.8008 & 300 & 18.7138 & 300 & 18.4637 \\
\hline 400 & 19.9775 & 400 & 19.9368 & 400 & 19.8706 & 400 & 19.7423 & 400 & 19.3817 \\
\hline 500 & 20.8596 & 500 & 20.8041 & 500 & 20.7541 & 500 & 20.5421 & 500 & 20.0659 \\
\hline
\end{tabular}

TABLE 6

SIMULATION FOR 10 YEARS

\begin{tabular}{|c|c|c|c|c|}
\hline Fc $=5000 \mathrm{md} . \mathrm{ft}$ & $\mathrm{Fc}=4000 \mathrm{md} . \mathrm{ft}$ & $\mathrm{Fc}=3000 \mathrm{md} . \mathrm{ft}$ & $\mathrm{Fc}=2000 \mathrm{md} . \mathrm{ft}$ & $\mathrm{Fc}=1000 \mathrm{md} . \mathrm{ft}$ \\
\hline
\end{tabular}

$17^{\text {th }}$ LACCEI International Multi-Conference for Engineering, Education, and Technology: "Industry, Innovation, And Infrastructure for Sustainable Cities and Communities", 24-26 July 2019, Jamaica. 


\begin{tabular}{|c|c|c|c|c|c|c|c|c|c|}
\hline Xf (ft) & Gp (bscf) & Xf (ft) & Gp (bscf) & Xf (ft) & Gp (bscf) & Xf (ft) & Gp (bscf) & Xf (ft) & Gp (bscf) \\
\hline 100 & 17.8955 & 100 & 17.889 & 100 & 17.87720 & 100 & 17.85390 & 100 & 17.78470 \\
\hline 200 & 20.2118 & 200 & 20.1957 & 200 & 20.168 & 200 & 20.1128 & 200 & 19.9526 \\
\hline 300 & 21.742 & 300 & 21.7133 & 300 & 21.6641 & 300 & 21.5719 & 300 & 21.3062 \\
\hline 400 & 22.9214 & 400 & 22.8789 & 400 & 22.8091 & 400 & 22.674 & 400 & 22.2935 \\
\hline 500 & 23.8684 & 500 & 23.8104 & 500 & 23.7082 & 500 & 23.5277 & 500 & 23.027 \\
\hline
\end{tabular}

To obtain the optimum value of cumulative gas production, a comparison of simulation results was performed. The hydraulic fracture with fracture half-length and fracture conductivity of $500 \mathrm{ft}$ and $5000 \mathrm{md}$.ft respectively produced
23.87 bscf of cumulative gas in 10 years. The results of Gp at different fracture half-length for different years are shown in Table 7 and Figure 6.

TABLE 7

OPTIMUM VALUE OF GP

\begin{tabular}{|c|c|c|c|c|c|c|c|c|c|}
\hline \multicolumn{2}{|c|}{$\mathrm{Xf}=100(\mathrm{ft})$} & \multicolumn{2}{c|}{$\mathrm{Xf}=200(\mathrm{ft})$} & \multicolumn{2}{c|}{$\mathrm{Xf}=300(\mathrm{ft})$} & \multicolumn{2}{c|}{$\mathrm{Xf}=400(\mathrm{ft})$} & \multicolumn{2}{|c|}{$\mathrm{Xf}=500(\mathrm{ft})$} \\
\hline \multicolumn{2}{|c|}{$\mathrm{Fc}=5000 \mathrm{md} . \mathrm{ft}$} & \multicolumn{2}{|c|}{$\mathrm{Fc}=5000 \mathrm{md} . \mathrm{ft}$} & \multicolumn{2}{|c|}{$\mathrm{Fc}=5000 \mathrm{md} . \mathrm{ft}$} & \multicolumn{2}{|c|}{$\mathrm{Fc}=5000 \mathrm{md} . \mathrm{ft}$} & \multicolumn{2}{|c|}{$\mathrm{Fc}=5000 \mathrm{md} . \mathrm{ft}$} \\
\hline $\mathrm{t}$ & $\mathrm{Gp}(\mathrm{bscf})$ & $\mathrm{t}$ & $\mathrm{Gp}(\mathrm{bscf})$ & $\mathrm{t}$ & $\mathrm{Gp}(\mathrm{bscf})$ & $\mathrm{t}$ & $\mathrm{Gp}(\mathrm{bscf})$ & $\mathrm{t}$ & $\mathrm{Gp}(\mathrm{bscf})$ \\
\hline 5 & 10.85530 & 5 & 12.5343 & 5 & 13.7014 & 5 & 14.6236 & 5 & 15.3766 \\
\hline 8 & 15.33050 & 8 & 17.4542 & 8 & 18.8744 & 8 & 19.9775 & 8 & 20.8596 \\
\hline 10 & 17.89550 & 10 & 20.2118 & 10 & 21.742 & 10 & 22.9214 & 10 & 23.8684 \\
\hline
\end{tabular}

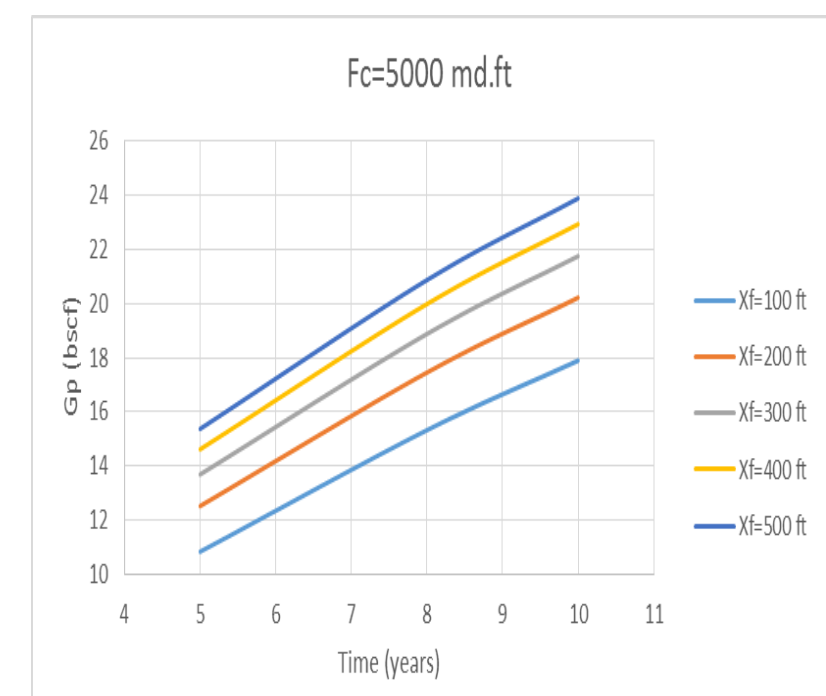

Fig. 6 Performance of hydraulic fracture at different half-length fracture shown in the next table 8 and Figure 10. Using the reservoir data detailed previously, the plots of 1/Q against time on tracing paper were created in a $\log -\log$ scale as shown in Figure 7, 8 and 9. The curve fitting of the method is achieved displacing the tracing paper horizontally and vertically along the type curve until a match is obtained.

TABLE 8

SPECIFIC FCD AND XF VALUES TO GENERATE TYPE CURVES IN

\begin{tabular}{|c|c|}
\hline $\begin{array}{c}\text { WELL \#1 } \\
\text { FCD } \\
\text { (dimensionless) }\end{array}$ & $\mathrm{Xf}(\mathrm{ft})$ \\
\hline 50 & 200 \\
\hline 1000 & 100 \\
\hline 5000 & 75 \\
\hline
\end{tabular}

The results of type curve in the second section shows a perfect matching for both well \#1 and \#4. A range of dimensionless fracture conductivity and fracture half-length was selected to generate three type curve for both wells as

$17^{\text {th }}$ LACCEI International Multi-Conference for Engineering, Education, and Technology: "Industry, Innovation, And Infrastructure for Sustainable Cities and Communities", 24-26 July 2019, Jamaica. 


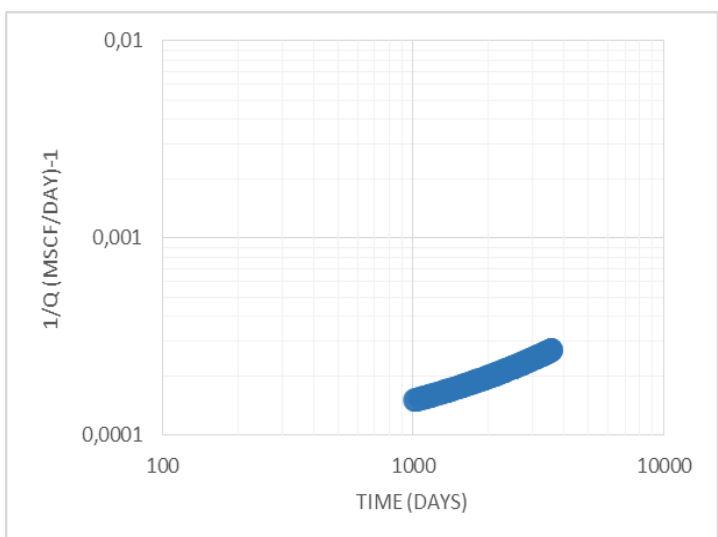

Fig. 7 1/q vs Time in log-log paper for $F_{C D}=50$ and $X f=200 \mathrm{ft}$

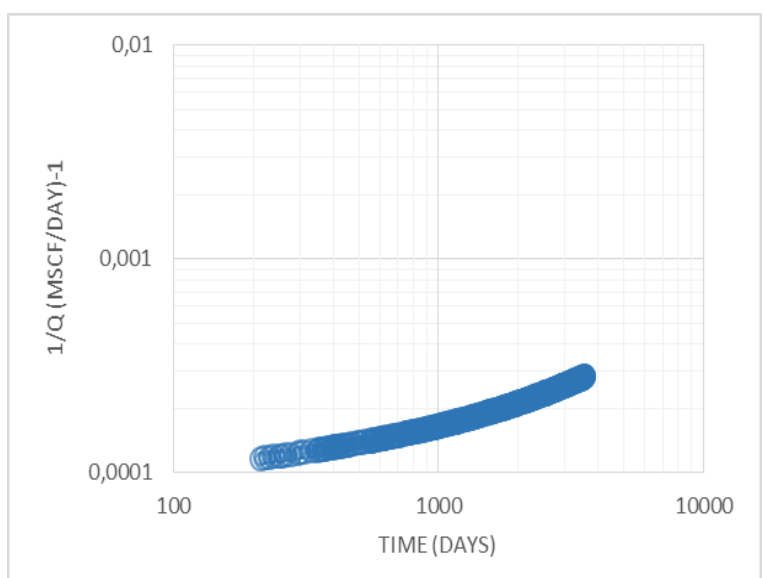

Fig. 8 1/q vs Time in $\log$-log paper for $\mathrm{F}_{\mathrm{CD}}=1000$ and $\mathrm{Xf}=100 \mathrm{ft}$

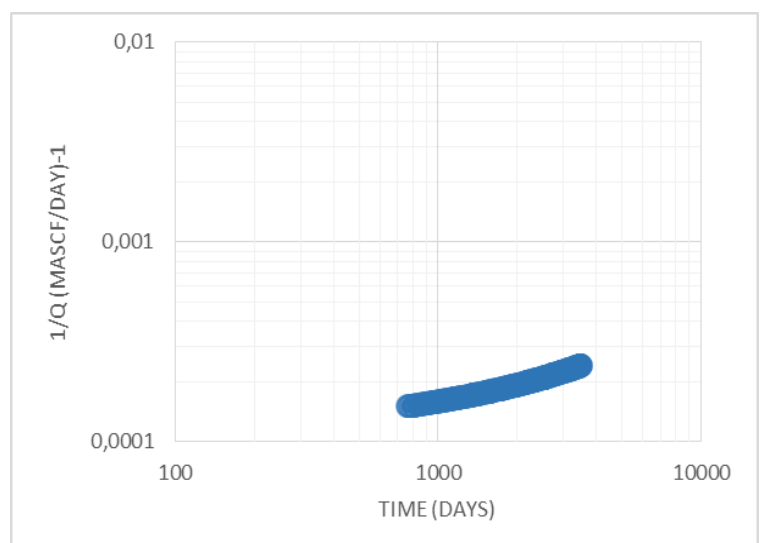

Fig. 9 1/q vs Time in $\log -\log$ paper for $F_{C D}=5000$ and $X f=200 \mathrm{ft}$

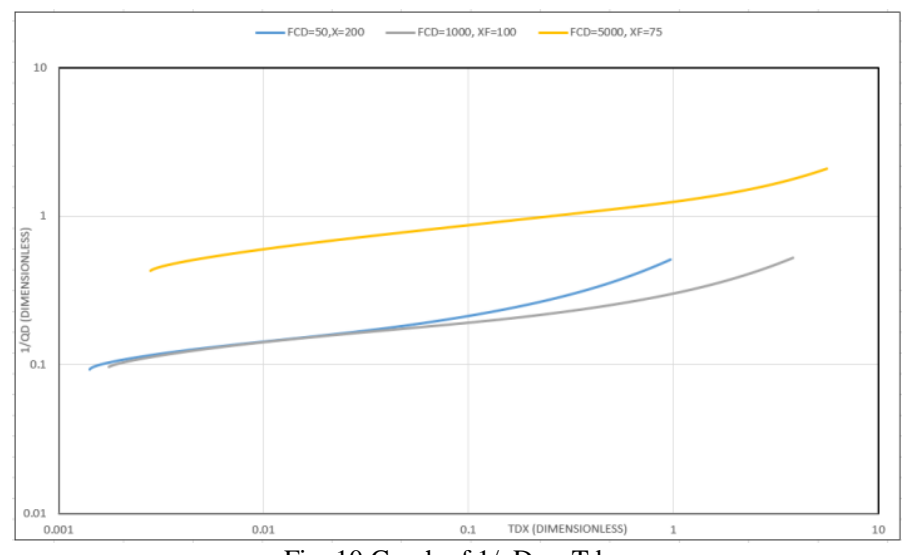

Fig. 10 Graph of $1 / \mathrm{qD}$ vs Tdx

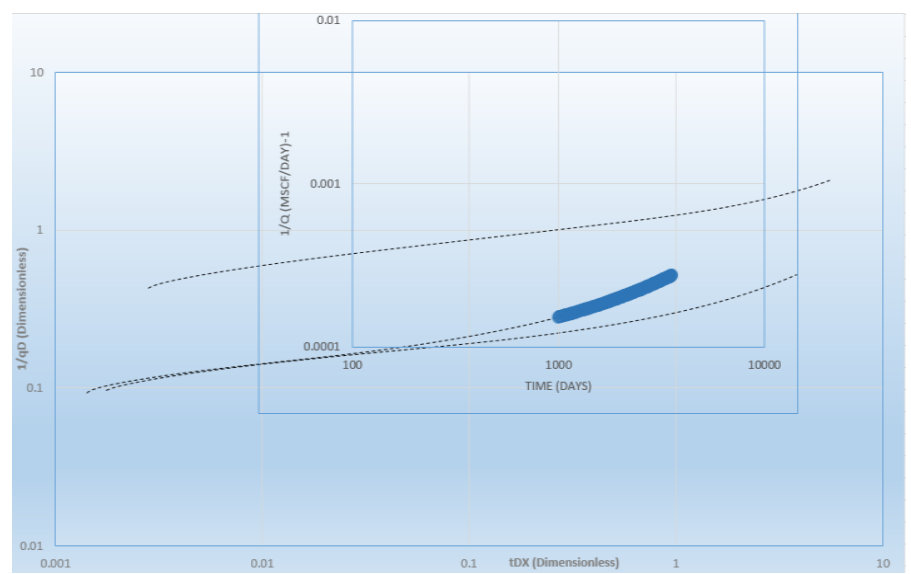

Fig. 11 Matching technique for $F_{C D}=50$ and $X f=200 \mathrm{ft}$

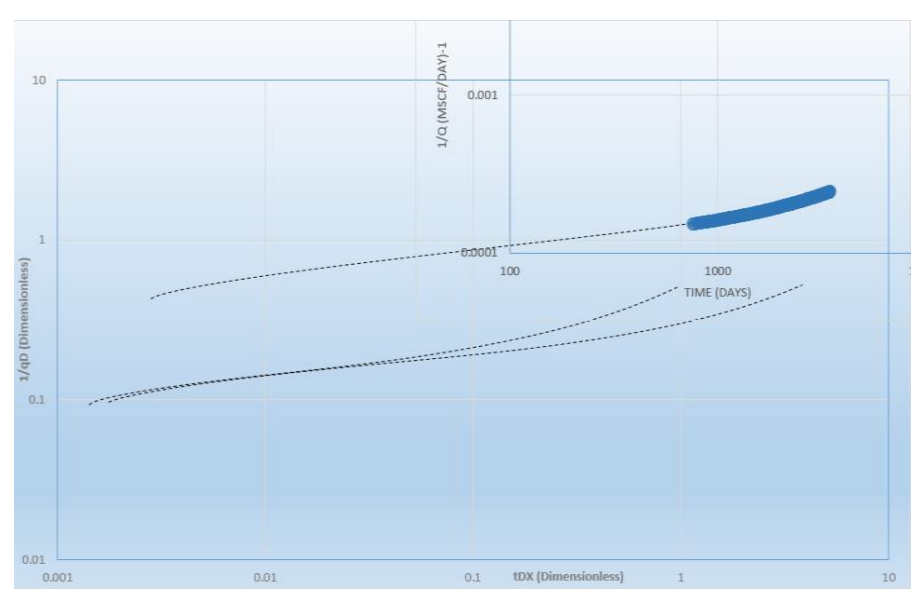

Fig. 12 Matching Technique for $\mathrm{F}_{\mathrm{CD}}=5000$ and $\mathrm{Xf}=75 \mathrm{ft}$

$17^{\text {th }}$ LACCEI International Multi-Conference for Engineering, Education, and Technology: "Industry, Innovation, And Infrastructure for Sustainable Cities and Communities", 24-26 July 2019, Jamaica. 


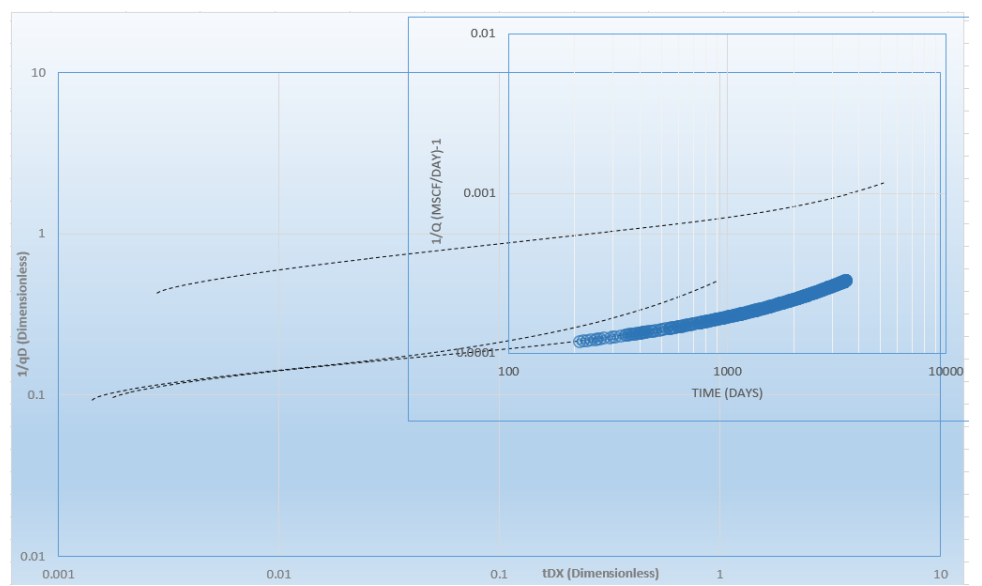

Fig. 13 Matching Technique for $\mathrm{F}_{\mathrm{CD}}=1000$ and $\mathrm{Xf}=100 \mathrm{ft}$

\section{CONCLUSIONS AND RECOMMENDATIONS}

Based on the result from the first and second section, several conclusions were drawn:

For Tight Gas Reservoir, the optimization of gas production can be performed using optimum fracture halflength and fracture conductivity with values of $500 \mathrm{ft}$ and 5000 $\mathrm{md} * \mathrm{ft}$. This numerical result shows a more optimum scenario than $100 \mathrm{ft}, 200 \mathrm{ft}, 300 \mathrm{ft}$ and $400 \mathrm{ft}$ as well as $4000 \mathrm{md} * \mathrm{ft}$, $3000 \mathrm{md}^{*} \mathrm{ft}, 2000 \mathrm{md}^{*} \mathrm{ft}$ and $1000 \mathrm{md}^{*} \mathrm{ft}$.

The use of LGR method in numerical simulator is highly recommended for hydraulic fracture modelling in vertical fractured tight gas wells. The result simulation, including cumulative $\mathrm{Gp}$, were validated, and proved on the type curve through matching technique by Agarwal, Carter et al. (1979) [9].

The type curve for Low-Permeability Gas Well Stimulated by MHF is still a valid method for tight gas reservoir, in which the calculation of $1 / q_{D}$ is a function of real gas pseudopressure.

The Constant Pressure, Finite Flow-Capacity type curves are suitable for hydraulic fractured well in tight gas reservoir. Considering the tight gas well to produce at a constant bottom hole pressure, the well-pressure type curves are appropriate for evaluating simulation data.

\section{Nomenclature}

$\begin{array}{ll}t_{D_{X f}} & \text { Dimensionless time } \\ K & \text { Formation permeability, mD } \\ t & \text { Time, hours } \\ X_{f} & \text { Half fracture length, } \mathrm{ft}\end{array}$

$\begin{array}{ll}\Phi & \text { Porosity, fraction } \\ h & \text { Formation thickness, } \mathrm{ft} \\ c_{t} & \text { Total Compressibility, } 1 / \mathrm{psi} \\ \mathrm{Q} & \text { Flow rate, Mscf/D } \\ 1 / \mathrm{q}_{\mathrm{D}} & \text { Reciprocal dimensionless rate } \\ \mu & \text { Viscosity, } \mathrm{cp} \\ \mathrm{T}^{\circ} & \text { Temperature, Rankin } \\ \Delta[\mathrm{m}(\mathrm{p})] \text { Difference in real gas pseudo-pressure, } \mathrm{psi}^{2} / \mathrm{cp} \\ \mathrm{F}_{\mathrm{CD}} \quad \text { Dimensionless fracture flow capacity } \\ \mathrm{k}_{\mathrm{f}} \mathrm{W} & \text { Fracture conductivity, } \mathrm{mD} * \mathrm{ft}\end{array}$

\section{REFERENCES}

[1] Iwere, F. O., et al. (2004). Numerical Simulation of thick, tight fluvial sands. SPE Annual Technical Conference and Exhibition, Society of Petroleum Engineers.

[2] Wattenbarger, R., et al. (1998). Production Analysis of Linear Flow Into Fractured Tight Gas Wells. Paper SPE 39931 presented at the SPE Rocky Mountain Regional/Low-Permeability Reservoirs Symposium, Denver, Colorado, 5-8 April. Low-Permeability Reservoirs Symposium, Denver, $\mathrm{CO}$, April 5.

[3] El-Ahmady, M. H. (2004). Coarse scale simulation of tight gas reservoirs, Texas A\&M University.

[4] Nghiem, L. X. (1983). "Modeling infinite-conductivity vertical fractures with source and sink terms." Society of Petroleum Engineers Journal 23(04): 633-644.

[5] Abacioglu, Y., et al. (2009). Advancing reservoir simulation capabilities for tight gas reservoirs. SPE Rocky Mountain Petroleum Technology Conference, Society of Petroleum Engineers.

[6] Bonney, K. E., et al. (2013). Case History of Using Integrated Reservoir Modeling Workflow for Tight Gas Reservoirs. SPE Unconventional Gas Conference and Exhibition, Society of Petroleum Engineers.

[7] Azim, R. A. and S. S. Abdelmoneim (2013). "Modeling hydraulic fractures in finite difference simulators using amalgam local grid refinement (LGR)." Journal of Petroleum Exploration and Production Technology 3(1): 21-35.

[8] Western Australian Energy Research Alliance (wa:era) 2012, Whicher Range tight gas sands study: Geological Survey of Western Australia, Report 112, 405p.

[9] Agarwal, R., et al. (1979). "Evaluation and performance prediction of low-permeability gas wells stimulated by massive hydraulic fracturing." Journal of Petroleum Technology 31(03): 362-372.

[10] Theis, C. V. (1935). "The relation between the lowering of the Piezometric surface and the rate and duration of discharge of a well using ground-water storage." Eos, Transactions American Geophysical Union 16(2): 519-524

[11] Ostojic, J., et al. (2012). "Production performance of hydraulic fractures in tight gas sands, a numerical simulation approach." Journal of Petroleum Science and Engineering 88: 75-81.

[12] Pankaj, P. and V. Kumar (2010). Well testing in tight gas reservoir: today. SPE Oil and Gas India Conference and Exhibition, Society of Petroleum Engineers.

$17^{\text {th }}$ LACCEI International Multi-Conference for Engineering, Education, and Technology: "Industry, Innovation, And 